\title{
DISPERSAL OF TERRESTRIAL GASTROPODS BY BIRDS DURING THE NESTING PERIOD
}

\author{
EVGENIY V. SHIKOV ${ }^{1 *}$, ANDREI A. VINOGRADOV ${ }^{2}$ \\ ${ }^{1}$ Kalinina 37-21, Lyubertsy, Moscow Region, 140002, Russia (e-mail: e_v_schik@mail.ru) \\ ${ }^{2}$ Tver State University, Faculty of Biology, Department of Zoology, Prospect Chaikovskogo 70a, Tver, Russia \\ *corresponding author \\ ABSTRACT: We observed a blackcap Sylvia atricapilla L. (Sylviidae) which carried terrestrial gastropods \\ Fruticicola fruticum (O. F. Müller) (Bradybaenidae) and Zonitoides nitidus (O. F. Müller) (Zonitidae) in a decid- \\ uous forest. Similarly, a blackbird Turdus merula L. (Turdidae) was observed carrying a slug, Arion subfuscus s. 1. \\ (Arionidae), in a dry pine forest. Z. nitidus was transported over a distance of at least $48 \mathrm{~m}$, while A. subfuscus, \\ no less than $25 \mathrm{~m}$. The possibility of terrestrial gastropod dispersal by birds during the chick-feeding period is \\ discussed.
}

KEY WORDS: terrestrial Gastropoda, Fruticicola fruticum, Zonitoides nitidus, Arion subfuscus, dispersal, birds, Sylvia atricapilla, Turdus merula

\section{INTRODUCTION}

Home ranges of land gastropods vary widely in size, as their radius ranges from several decimetres for small-sized species to several dozen metres for the big ones (E. V. SHIKOV, unpublished). Many land gastropod species are stenoecious, and this considerably limits their dispersal abilities. Not only wide roads but even narrow forest paths may turn out to be impenetrable barriers for snails. Therefore, passive dispersal is of special importance for them - they can be carried by wind, water, mammals, birds, and people (REES 1965, DundeE et al. 1967, VAGVOLGYI 1975, 1978, SHIKOV 1977, 1981, FISHER et al. 1996, KIRCHNER et al. 1997, DÖRGE et al. 1999, HORNUNG et al. 2003, KAWAKAMi et al. 2008, BEINLiCH \& PlACHTER 2010, MACIOROWSKI et al. 2012).

Land snails can be accidentally or deliberately transported by birds. Birds of numerous species bring snails to their chicks as food (AKRAMOVSKIY 1970, KISS et al. 1978, KORNYUSHIN et al. 1984, BEREZANTSEVA 1997, BELSKIY et al. 1998, Allen 2004, ZEMOGLYADCHUK 2004, ROSIN et al. 2011). However, data on the distances over which the snails are carried by birds are scarce (KIRCHNER et al. 1975, VAGVOLGYI $1975,1978)$. Here we provide more information on the distances over which terrestrial gastropods can be dispersed by birds.

\section{MATERIAL AND METHODS}

Bird nests built in habitats with poor mollusc fauna were chosen for this research. A. A. VINOGRADOV did long-term observations of birds feeding their chicks there. Birds bringing land snails for their chicks were registered. E. V. SHIKOV studied the malacofauna of the habitats surrounding the nests. The chick-feeding observations included pho- tos and video recordings with an automated candid camera. The malacological part of the study was carried out using traditional methods (LIKHAREV \& RAMMELMEIER 1953); the nomenclature follows SHILEYKO (2004) and SYSOEV \& SHILEYKO (2005). Weight of individuals living in wet conditions was determined with a scale. The plant associations were 
classified according to NEVSKIY (1960) and RYSIN \& SAVELYEVA (2008).

Feeding chicks with snails was observed primarily in a blackcap (Sylvia atricapilla L.) nest located in the western part of the Beriozovaya Rotscha Park in the city of Tver, Russia. The park was planted in the early 20th century, replacing cultivated fields and meadows. At first it was composed of birch trees only. Later, the park did not get proper maintenance, and now its western part resembles a natural deciduous forest. The park is situated on a plain, and the microrelief is not prominent. The soil is clayey. The trees include Betula pendula Ehrhart, Populus tremula L., Alnus incana Moench, Fraxinus excelsior L., the shrubs Rhamnus frangula Miller, Corylus avellana L., Sambucus nigra L. and Sorbus aucuparia L. The herb layer is scanty and composed of Aegopodium podagraria L., Geum rivale L., Lysimachia nummularia L., Urtica dioica L., and other herbs. The litter consists of leaves and twigs, and is $2-5 \mathrm{~cm}$ thick. The observations of the blackcap nest were conducted in daylight on 20-25 June 2010. Photographs of the birds near the nest were taken daily from 11:00 to 14:00.

A blackbird (Turdus merula L.) nest was observed $55 \mathrm{~km}$ south of Tver, in the vicinity of Feryazkino village in the Tver Region. The nest was located on a pine tree in a Pinetum hylocomiosum purum forest. The observations were conducted in daytime, on 7-25 June 2011, and 2-3 video sessions were held daily. Each session lasted 2 hours.

\section{RESULTS AND DISCUSSION}

On 23 June 2010, approximately at noon, A. A. VINOGRADOV took a series of photos of the blackcap at its nest in the deciduous forest. The photos clearly show the bird holding a butterfly larva and two snails in its beak (Figs 1-4). The shells of both snails appear intact. The big snail in the foreground is a young Fruticicola fruticum (O. F. Müller, 1774) of the family Bradybaenidae. As can be seen through the slightly translucent shell, the snail's body is retracted. The bird is holding $F$. fruticum by the edge of the shell. The shell has 3.1 whorls, so the snail is a juvenile (adults of the species have shells of 4-5.4 whorls). In wet weather period, the snails with this whorl number weigh from 100 to $130 \mathrm{mg}$. The smaller dark snail in Figs 1-4 is Zonitoides nitidus (O. F. Müller, 1774) of the family Zonitidae. The snail is an adult. The adult weight of the species ranges from 49 to $66 \mathrm{mg}$.

In order to determine the possible source of the snails, we observed the western part of the Beriozovaya Rotscha Park, where the nest was located. Its malacofauna is characteristic of planted deciduous forests and includes Cochlicopa lubrica (O. F. Müller), Trochulus hispidus L., F. fruticum, Arion fasciatus (Nilsson) and Succinea putris L. Since F. fruticum occurs in the whole western part of the park, the place where the bird found it could not be determined. By contrast, Zonitoides nitidus is a hygrophile, and the nearest site where it occurs is $48 \mathrm{~m}$ away from the blackcap nest. The site is a wet silted bank of a small stream, inhabited by hygrophiles: $S$. putris, Deroceras laeve (O. F. Müller), Vallonia pulchella (O. F. Müller), Z. nitidus, Pseudotrichia rubiginosa (Schmidt), and slugs. Other places inhabited by $Z$. nitidus in the same part of the park are farther away from the nest: 67 and $96 \mathrm{~m}$, respectively. Therefore, it can be assumed that the blackcap transports $Z$. nitidus over distances of not less than $48 \mathrm{~m}$.

A series of photos of the blackbird with a slug was taken on 23 June 2011 at 11 AM in the coniferous for- est. The photos show the bird holding Arion subfuscus (Draparnaud, 1805) s. l. of the family Arionidae in its beak and then feeding it to its chick (Figs 5-7). The uniformly brown colour of the slug dorsum indicates an adult. In that forest, the average adult weight of the species was $1.4 \mathrm{~g}$.

Pinetum hylocomiosum purum forests are very dry and not inhabited by A. subfuscus (SHIKOV 1981). On the sandy soils there are also various mosses, such as Pleurozium schreberi (Brid.) Mitt., Dicranum schraderi

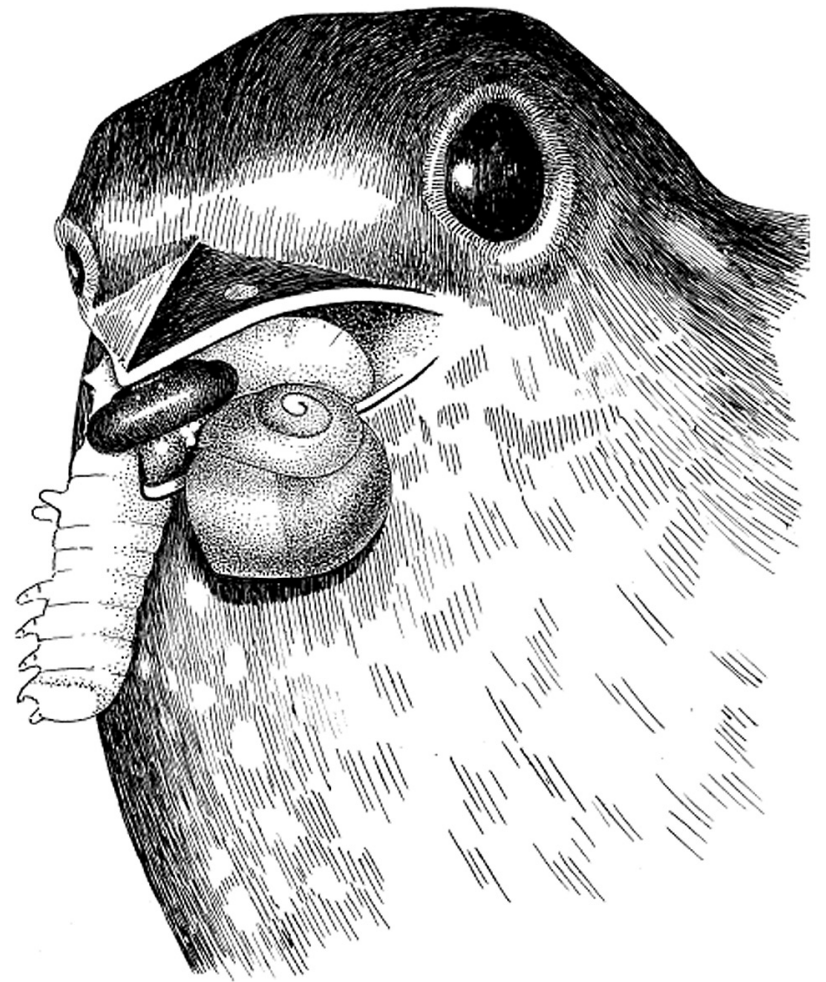

Fig. 1. Blackcap Sylvia atricapilla L. at its nest, with a butterfly larva, Fruticicola fruticum (O. F. Müller) and Zonitoides nitidus (O. F. Müller). (Drawn by E. V. SHIKOV from a photo by A. A. VINOGRADOV) 

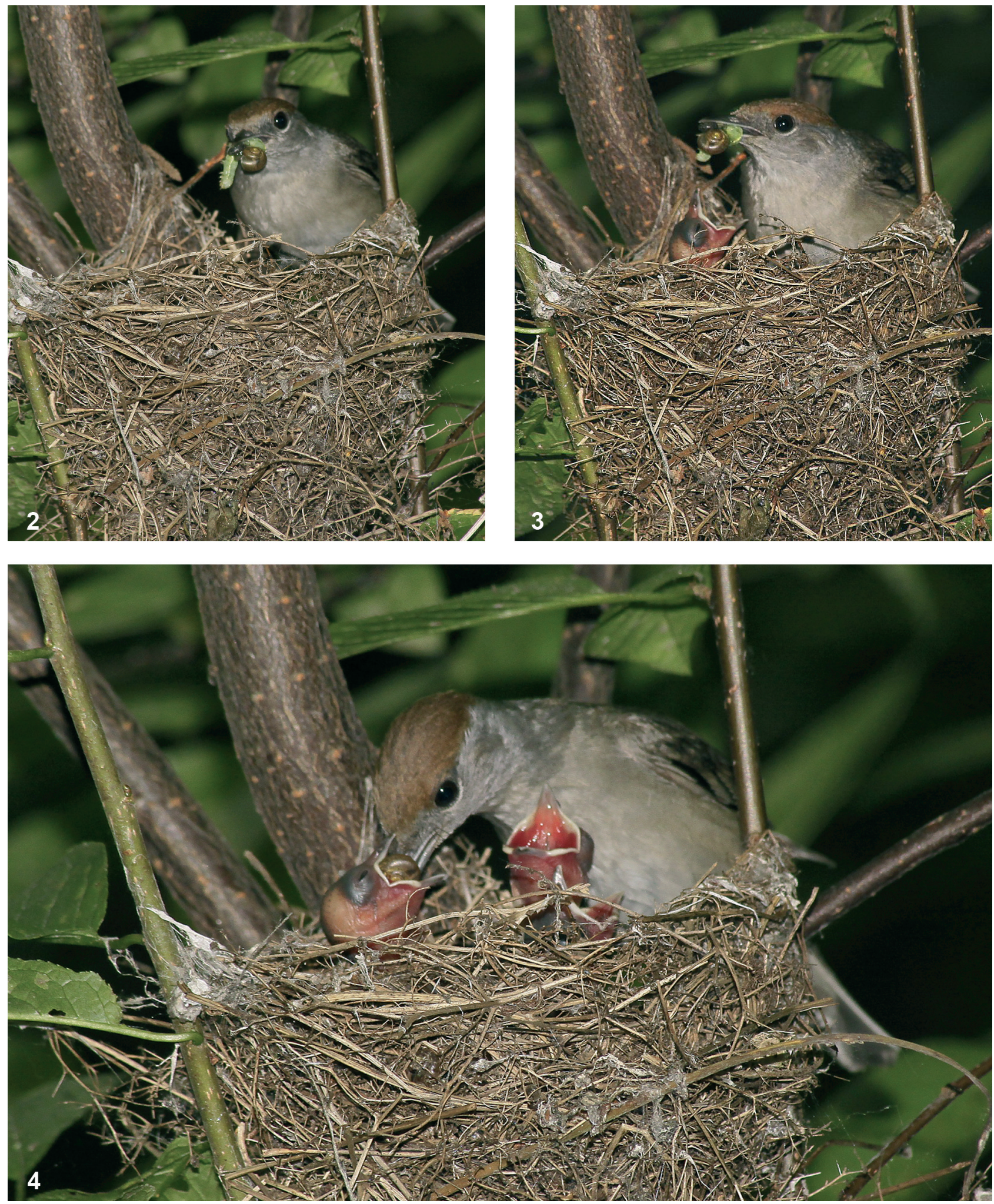

Figs 2-4. Blackcap Sylvia atricapilla L. at its nest, with a butterfly larva, Fruticicola fruticum (O. F. Müller) and Zonitoides nitidus (O. F. Müller). (Photos: A. A. VinOGRADOV)

Wahlenb., Ceratodon purpureus (Hedw.) Brid. and many others. The pine tree with the blackbird nest was located on a hill slope. Down along the slope, Pinetum hylocomiosum purum was replaced by Pinetum vacciniosum, and then by Pinetum myrtillosum. Pinetum vacciniosum was also a dry forest with Vaccinium vitis idaea L. and Melampyrum pratense L. apart from the mosses. No gastropods were found there. Pinetum myrtillosum was moderately moist. Its shrub layer consisted of Vaccinium myrtillus L. There were many herb 


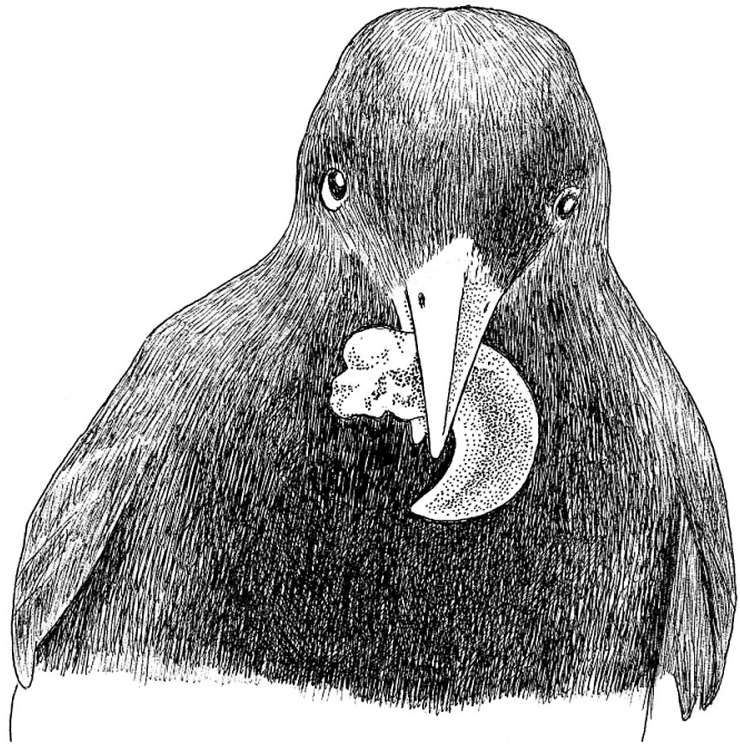

Fig. 5. Blackbird Turdus merula L. at its nest, with Arion subfuscus (Drap.) s. 1. (Drawn by E.V. SHIKOV from a photo by A. A. VINOGRADOV)

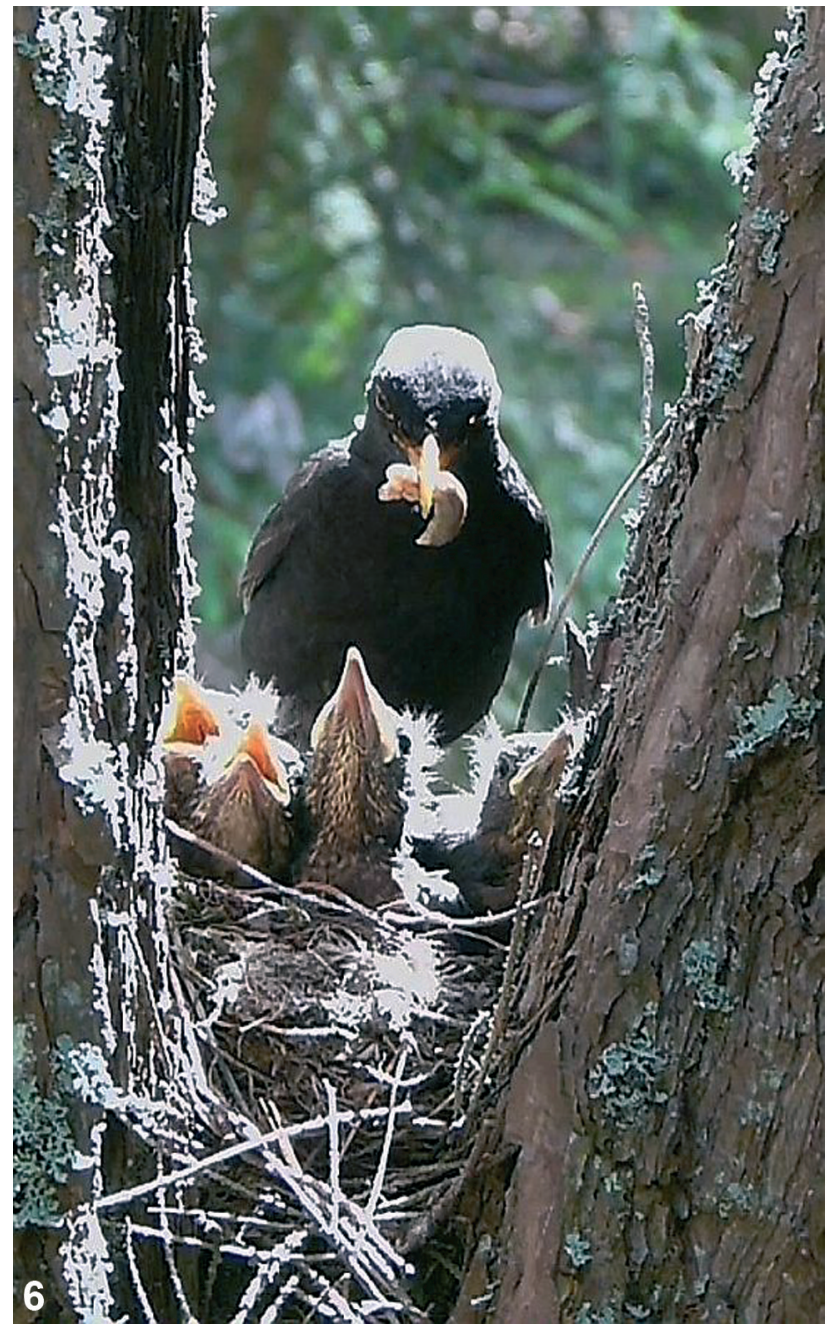

species, such as Lusula pilosa Willd., Calamagrostis arundinacea Roth., C. lanceolata Roth., Viola canina L., Pirola rotundifolia $\mathrm{L}$. and others. It was the only place where A. subfuscus and some other gastropod species Vitrina pellucida pellucida (O. F. Müller, 1774), Perpolita hammonis (Strøm, 1765) and Euconulus fulvus (O. F. Müller, 1774) were recorded. Therefore, the bird had carried the slug over a distance of at least $27 \mathrm{~m}$.

Feeding their chicks, adult birds sometimes loose some of the food they transport to the nest. Birds can accidentally drop their prey on their way to the nest as well as at the nest itself. Besides, the chicks regurgitate some hard-covered invertebrates (BELSKIY et al. 1998, GRAVELAND 1996; A. A. VINOGRADOV, unpublished).

We have observed many bird species feeding their chicks. Initially the bird puts the food it has brought into the chick's open beak but the chick does not always swallow it at once. If it does not close its beak for a long time, the parent will take part of the food away from the chick's open beak and put it into the beaks of the other chicks. Doing this, the parent bird sometimes accidentally drops some parts of the food onto the nest edges and beyond it. The snails that fall onto

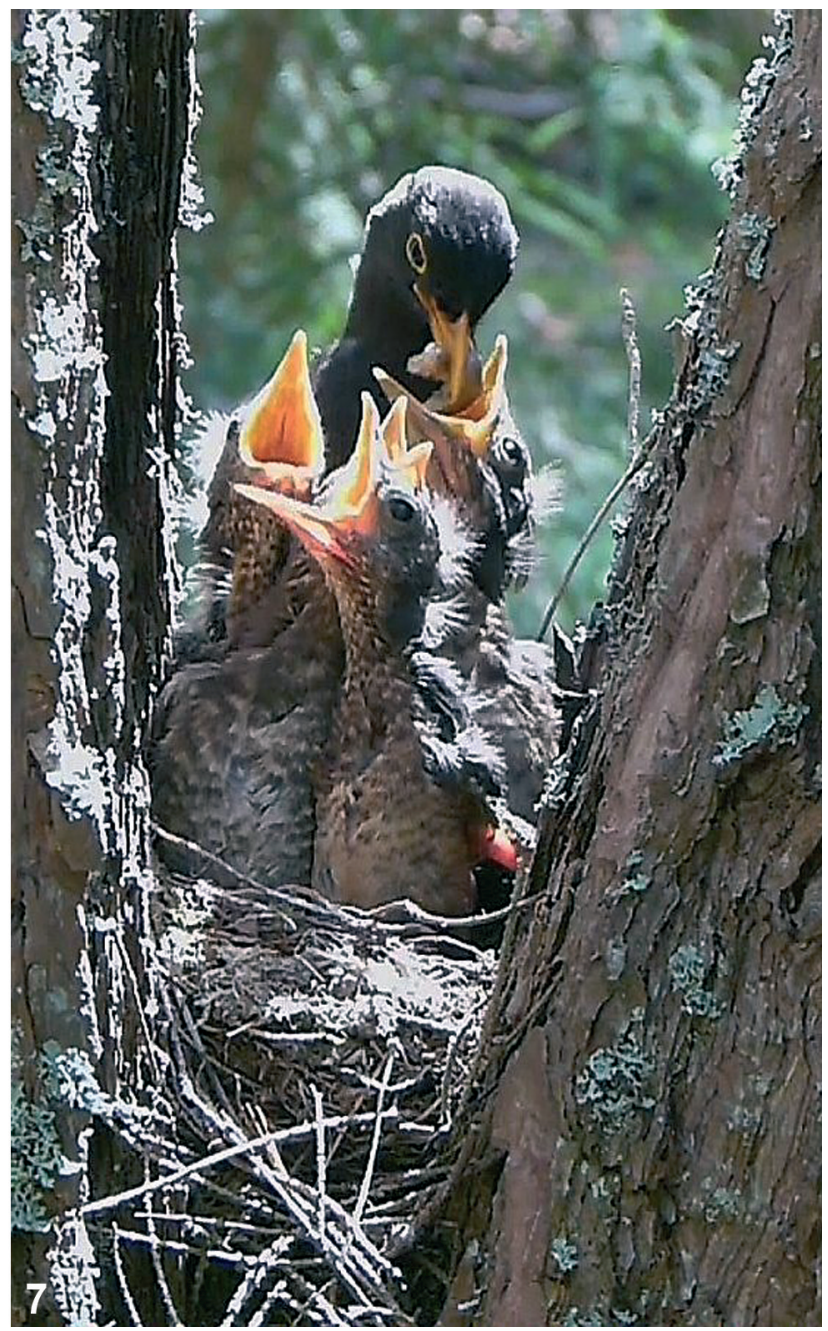

Figs 6-7. Blackbird Turdus merula L. at its nest, with Arion subfuscus (Drap.) s. 1. (Photos: A. A. VINOGRADOV) 
the ground may find suitable conditions there. In such cases, birds accidentally aid the spread of gastropods. For terrestrial gastropods this is of considerable significance, considering their very limited capability of active dispersal resulting from slow movement and often strict ecological requirements regarding moisture, litter quality, food, shelters, etc. For example, in natural habitats, Z. nitidus usually moves $1-2 \mathrm{~m}$ a year (E. V. SHIKOV, unpublished).

Gastropods can be carried considerably farther than we have succeeded to prove. According to our data, the blackcap usually forages for food for its chicks within 30 to $50 \mathrm{~m}$ from the nest but sometimes, when searching for food, it can cover a distance of more than $100 \mathrm{~m}$. Besides, we have recorded blackbirds bringing to their nest larvae of aquatic beetles (Dytiscidae, Macrodytes sp.) from a pond about $300 \mathrm{~m}$ away.

The role of birds in slug dispersal requires further studies. Fig. 5 shows the anterior part of A. subfuscus, badly deformed and possibly pecked. We have not recorded any live slugs to be carried by birds but simple pressing of a slug with a bird's beak usually does not cause death.

\section{REFERENCES}

AKRAMOVSKIY N. N. 1970. Biotsenoticheskiye svyazi mollyuskov Armenii i o roli etikh zhivotnykh v krugovorote veshchestva i energii. Zool. Sb. AN Arm. SSR 5: 138-142.

ALLEN J. A. 2004. Avian and mammalian predators of terrestrial gastropods. In: BARKER G. M. (ed.). Natural enemies of terrestrial molluscs. CABI Publishing, Wallingford. doi: 10.1079/9780851993195.0001

Beinlich B., Plachter H. 2010. Sheep a functional corridor system. In: Plachter H., Hampicke U. (eds). Largescale livestock grazing. A management tool for nature conservation. Springer Verlag, Berlin, pp. 281-288.

BELSKIY E. A., KHOKHUTKIN I. M., GREBENNIKOV M. E. 1998. Mollyuski v pitanii nekotorykh lesnykh ptits v yuzhnoy tayge Urala. Rus. Ornithol. J. 1998, Express no. 44: 13-18.

BEREZANTSEVA M. S. 1997. Pitaniye ptentsov pevchego drozda Turdus philomelos v lesostepnoy dubrave «Les na Vorskle». Rus. Ornithol. J. 1997, Express no. 12: 8-15.

Dörge N., Walther C., Beinlich B., Plachter H. 1999. The significance of passive transport for dispersal in terrestrial snails (Gastropoda, Pulmonata). ZÖN 8: 1-10.

DundeE D. S., PhILliPS P. H., Newsom J. D. 1967. Snails on migratory birds. Nautilus 80: 89-91.

Fisher S. F., POSCHLOD P., BEINLICH B. 1996. Experimental studies on the dispersal of plants and animals on sheep in calcareous grasslands. J. Appl. Ecol. 33: 1206-1222. doi: $10.2307 / 2404699$

GRAVELAND J. 1996. Avian eggshell formation in calcium-rich and calcium-poor habitats: importance of snail shells and
Carrying live snails by birds may in many cases explain the appearance of accidental faunal components in various habitats and biotopes. For example, Succinea putris and Perforatella bidentata (Gmelin) do not inhabit Pinus sylvestris - Vaccinium myrtillus and Pinus sylvestris - Vaccinium vitis-idaea forests of the Tver and Novgorod Regions (SHIKOV 1981). However, a single snail of the above species is found occasionally in such forests, brought in accidentally, and most probably by birds. Research in the surrounding habitats reveals that the nearest habitat of the accidental gastropod is 30 to $80 \mathrm{~m}$ away from the place where it was found in a habitat alien to it. The role of birds in terrestrial mollusc dispersal is of considerable importance for the formation of the malacofauna of natural and anthropogenic habitats as well as for natural forest fauna reconstruction after fires, wood cutting, extreme drought, etc.

\section{ACKNOWLEDGEMENTS}

I thank Professor ANDRZEJ LESICKI for his valuable comments that helped me in refining this paper. The English translation was verified by SYLWIA UFNALSKA.

anthropogenic calcium sources. Can. J. Zool. 46: 1035-1044. doi: 10.1139/z96-115

Hornung E., Majors G., Feher Z., VArga A. 2003. An overview of the Vertigo species in Hungary: their distribution and habitat preferences (Gastropoda: Pulmonata: Vertiginidae). Heldia 5: 51-57.

KAWAKAMi K., WADA S., CHIBA S. 2008. Possible dispersal of land snails by birds. Ornithol. Sci. 7: 167-171. doi: 10.2326/1347-0558-7.2.167

KirCHNER CH., KRÄTZNER R., WelteR-SCHUltes F. W. 1997. Flying snails - how far can Truncatellina (Pulmonata: Vertiginidae) be blown over the sea? J. Moll. Stud. 63: 479-487. doi: 10.1093/mollus/63.4.479

KISS J. B., RÉKÁSI J., RichNOVSKY A. 1978. Schnecken als Vogelnahrung in Rumänien. Soosiana 6: 35-44.

Kornyushin A. V., Petrusenko A. A., SMOgorzhevsky L. A. 1984. Nazemnyye mollyuski v pishche ptentsov skvortsa. Vestn. Zool. 5: 86-88.

LIKHAREV I. M., RAMMELMEIER E. S. 1952. Nazemnyye mollyuski fauny SSSR. Opredeliteli po faune SSSR. Izdatelstvo AN SSSR. Moscow, Leningrad.

MACiOROWSKi G., URbańSKA M., GIERSZAL H. 2012. An example of passive dispersal of land snails by birds - short note. Folia Malacol. 20: 139-141. doi: 10.2478/ v10125-012-0010-6

NeVsKIY M. L. 1960. Rastitelnost Kalininskoy oblasti. In: BOCharov M. M., GaVeman A. V., Shaposhnikov L. V., SHIROKOVA B.A., MAJEWSKIY V.I., NEVSKIY M. L., ZAKULENKOV L. D. (eds). Priroda i khozyaystvo Kalininskoy 
oblasti. Kalininskiy gosudarstvennyy pedagogicheskiy institut, Kalinin, pp. 287-389.

REES W. J. 1965. The aerial dispersal of Mollusca. Proc Malac. Soc. London 36: 269-282.

Rosin Z. M., Olborska P., SURMaCKi A., TRYJANOWSKi P. 2011. Differences in predatory pressure on snails by birds and mammals. J. Biosc. 36: 691-699. doi: 10.1007/ s12038-011-9077-2

RYSIN L. P., SAVElyeva L. I. 2008. Sosnovyye lesa Rossiyi. Tovarishchestvo nauchn. izd. KMK, Moskva.

SHIKOV E. V. 1977. O rasselenii nazemnykh mollyuskov vo vremya polovodiy. Zool. Zh. 56: 361-367.

SHIKOV E. V. 1981. Mollyuski khvoynykh lesov Valdayskoy vozvyshennosti i sopredelnykh territoriy. In: ZINOVIEV V. I., SOROKIN M. G., TOMASHEVSKIY K. E. (eds). Fauna Verkhnevolzhya, eyo okhrana i ispolzovanie. Izd. Kalininskogo Gosudarstvennogo Universiteta, Kalinin, pp. 28-45.

SHILEYKo A. A. 2004. Treatise on recent terrestrial pulmonate Molluscs. Part 12. Ruthenica, Supplement 2: $1627-1763$.
SYSOEV A. K., SHILEYKO A. A. 2005. Neformalnaya gruppa Stylommatophora. In: KANTOR YU. I., SYSOEV A. Katalog mollyuskov Rossii i soptedelenykh stran. Tovarishchestvo nauch. isd. KMK, Moskva, pp. 228-308.

VAGVOLGYI J. 1975. Body size, aerial dispersal and origin of the Pacific land snail fauna. Syst. Zool. 24: 465-488. doi: $10.2307 / 2412906$

VAGVOLGYI J. 1978. Why are so many minute land snail on the Pacific Islands: A response to Leon Croizat. Syst. Zool. 27: 213. doi: 10.2307/2412974

ZEMOGLYADCHUK K. V. 2004. Fakty nakhozhdeniya mollyuskov v gnëzdakh ptits. Tez. dakl. mizhnar. navuk. kanf. "Pryrodnaye assyarodze Palessya. Asablivastsi i perspektyvy razvitstsya". Vydavedstva Akademiya, Brest, Belarus, p. 97.

Received: July 11th, 2012

Revised: January 11th/February 2nd, 2013 Accepted: February 23rd, 2013 